\title{
The Main Components of Vehicle Exhaust Gases and Their Effective Catalytic Neutralization
}

\section{R. SASSYKOVA' ${ }^{1}$, Y. A. AUBAKIROV', S. SENDILVELAN² , ZH. KH.TASHMUKHAMBETOVA', M. F. FAIZULLAEVA ${ }^{3}$, K. BHASKAR ${ }^{4}$, A. A. BATYRBAYEVA ${ }^{1}$, R. G. RYSKALIYEVA ${ }^{1}$, B. B. TYUSSYUPOVA ${ }^{1}$, A. A. ZHAKUPOVA ${ }^{1}$ and M.A.SARYBAYEV ${ }^{1}$}

${ }^{1}$ Al-Farabi Kazakh National University, 71, al-Farabi ave., 050040, Almaty, Kazakhstan. ${ }^{2}$ Department of Mechanical Engineering, Dr. M.G.R Educational and Research Institute, University, Chennai, 600 095, India.

${ }^{3}$ Korkyt Ata Kyzylorda University, 29a Aiteke bi str., Kyzylorda, Kazakhstan.

${ }^{4}$ Department Automobile Engineering, Rajalakshmi Engineering College, Chennai, 602105, India.

${ }^{*}$ Corresponding author E-mail: larissa.rav @ mail.ru

http://dx.doi.org/10.13005/ojc/350112

(Received: November 26, 2018; Accepted: December 10, 2018)

\section{ABSTRACT}

The constantly increasing growth in the number of cars is one of the reasons for the deterioration of the ecological situation in cities and large settlements. In Kazakhstan, on a national scale, the share of motor vehicles in total emissions of pollutants into the atmosphere by all technogenic sources reaches on average $40 \%$, in the mass of industrial waste - $2 \%$. The content of toxic substances in the exhaust of diesel and gasoline engines varies and depends on the type of engine and mode of operation, as well as on the quality of the fuel, the composition of the combustible mixture in the engine cylinders, speed and driving conditions, ignition system and fuel control. The number of all toxic components in the exhaust gas exceeds the maximum permissible standards by tens and hundreds of times. One of the most reliable ways to reduce the toxicity of vehicle exhaust gases and remove harmful substances is the complete oxidation of exhaust components using catalytic compositions on metal or ceramic block carriers. The article accumulates data from the scientific literature about toxicity of different components of exhaust gases and catalytic neutralization of vehicle exhaust gases by various scientific schools.

Keywords: Ecology, Exhaust gases, Internal combustion engines, Block catalyst, Metallic carriers, Ceramic carriers

\section{INTRODUCTION}

The number of cars on Earth exceeds 1 billion. The main danger of the chemical components contained in the exhaust gases is that the components are so small that they are absorbed into the blood through the lung tissue and have a harmful effect on various human organs. Pollution of the atmosphere leads to a decrease in oxygen and an increase in carbon dioxide, which entails a number

This is an Open Access article licensed under a Creative Commons license: Attribution 4.0 International (CC- BY). Published by Oriental Scientific Publishing Company @ 2018

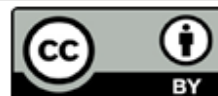


of stable weather changes. Researches of scientists show, that from year to year the maintenance of carbonic gas in atmosphere increases. This leads to the so-called "greenhouse effect", i.e. an increase in the average annual temperature on the planet by an average of $0.8-3 \%$, which, in turn, will lead to significant climate changes ${ }^{1-9}$.

Pollution of the air basin creates a real danger to human health. The predominant symptoms are irritation of the upper respiratory tract and eyes, asthma or allergic rhinitis, bronchitis, lung cancer, respiratory tract cancer, leading to a sharp increase in rachitis and a delay in the normal development of children. First of all, the central nervous system of a person is affected. Unlike other environmental factors, air comes into direct and rapid contact with very large, physiologically active surfaces of the human body. Every day a person inhales 15,000$20,000 \mathrm{~L}$ of air, so even relatively small amounts of any harmful substances, long inhaled with contaminated atmospheric air, adversely affect his health and often cause various diseases. To date, quite convincing material has been accumulated on the direct dependence of diseases of the respiratory, vision, digestion, heart, and blood vessels on the pollution of the atmosphere by the exhaust gases of motor vehicles.

In general, emissions of pollutants and greenhouse gases into the atmosphere from industrial activities and transport are formed from the emissions of stationary and mobile sources.

Petroleum fuels are among the main sources of environmental pollution. Road transport emissions relate to emissions from mobile sources and are determined by emissions of vehicle pollutants during their transport operations.

The aim of the article was to discuss harmful impact of exhaust gases of vehicles due to cars operation and to describe one of the promising ways of exhaust gases neutralization by means of catalysts on the blocks. The article collected and systematized the data published in modern domestic and foreign scientific sources.
The main components of the exhaust gases of transport

\section{General information}

Exhaust gases (off-gases) are the waste substances which are in the engine, they are products of oxidation and incomplete combustion of hydrocarbonic fuel ${ }^{10-12}$. Emissions of exhaust gases are the main reason for excess of admissible concentration of toxic substances and carcinogens in the atmosphere of the large cities, formations of the smogs which are the frequent reason of poisoning in selfcontained spaces. The amount of pollutants released into the atmosphere by vehicles is determined by the mass emission of gases and the composition of the exhaust gases.

It is necessary to note 3 main sources of air pollution with the toxic substances emitted by cars $^{13-16}$.

- $\quad$ The fulfilled gases which are going out of the muffler.

The crankcase gases coming to the atmosphere from the engine case ventilation system.

- $\quad$ The evaporating fuel getting to a surrounding medium from the fuel system of the engine and the fuel tank.

The work carried out showed strong air pollution in the cities. The application of satellite imagery shows a significant heterogeneity in the distribution of NO in the atmosphere, with heavier $\mathrm{NO}_{2}$ concentrating in the lower and NO in the upper layers of the atmosphere. The most dangerous consequences from the ecological point of view for the person and the nature caused by some products of combustion of fuels are given in Table 1. The quality of fuels has significant effect on formation of harmful emissions. Undesirable is the presence in the fuels of large amounts of olefinic and aromatic hydrocarbons, sulfur, ash components.

The qualitative and quantitative indicators of the release of harmful pollutants with exhaust gases of vehicles during their transport work are ambiguous and depend on many factors.

- $\quad$ On the type of the used fuel.

- $\quad$ From the design, conditions and operating conditions of the engine.

- $\quad$ On the amount of the done work.

- $\quad$ On the type and characteristics of the car's movement. 
Therefore real quantitative assessment in the atmosphere from the motor transport is a of emissions of pollutants and greenhouse gases difficult task ${ }^{17-24}$.

Table 1: Combustion products of fuels and their environmentally harmful effect ${ }^{25-29}$

\begin{tabular}{|c|c|c|c|}
\hline No & Name & Ecologically harmful consequences & Technical solutions \\
\hline 1 & Carbon monoxide & Toxic effect on humans and animals & $\begin{array}{l}\text { Optimization of the combustion process of fuels. } \\
\text { Application of additives }\end{array}$ \\
\hline 2 & Sulfur oxides & $\begin{array}{l}\text { Irritation of respiratory system; acid rain formation; } \\
\text { destruction of catalytic converters }\end{array}$ & Development of fuels with reduced sulfur content \\
\hline 3 & Nitrogen oxide & $\begin{array}{l}\text { Irritation of respiratory system; } \\
\text { the formation of acid rains and smog; } \\
\text { participation in the destruction of the } \\
\text { ozone screen }\end{array}$ & $\begin{array}{l}\text { Catalytic reduction of nitrogen oxides in } \\
\text { combustion products }\end{array}$ \\
\hline 4 & Hydrocarbons & $\begin{array}{l}\text { Carcinogenic action; } \\
\text { participation in the creation of the } \\
\text { greenhouse effect, the formation } \\
\text { of ozone and smog }\end{array}$ & $\begin{array}{l}\text { Reduction of saturated vapor pressure of fuels; } \\
\text { optimization of the combustion process, the } \\
\text { use of additives }\end{array}$ \\
\hline 5 & Ozone & $\begin{array}{l}\text { Toxic effect on flora and fauna; } \\
\text { participation in smog formation }\end{array}$ & $\begin{array}{l}\text { Reducing the emission of ozone-forming } \\
\text { substances: hydrocarbons and nitrogen oxides }\end{array}$ \\
\hline 6 & Aldehydes & $\begin{array}{l}\text { Irritant effect on organisms; } \\
\text { participate in the formation of smog }\end{array}$ & Improving the combustion process \\
\hline 7 & $\begin{array}{l}\text { Compounds of } \\
\text { lead and other } \\
\text { metals }\end{array}$ & $\begin{array}{l}\text { Toxic effect on flora and fauna; } \\
\text { violation of the balance of microelements } \\
\text { in water and soil; poisoning of afterburning } \\
\text { catalysts }\end{array}$ & $\begin{array}{l}\text { Development of fuels that do not contain metal } \\
\text { compounds }\end{array}$ \\
\hline 8 & $\begin{array}{l}\text { Particulate matter } \\
\text { and soot }\end{array}$ & $\begin{array}{l}\text { Carcinogenic action, participation in the } \\
\text { formation of smog and acid rain }\end{array}$ & $\begin{array}{l}\text { Decrease in ash content of fuels, reduction of } \\
\text { sulfur and aromatic hydrocarbons content }\end{array}$ \\
\hline
\end{tabular}

The main consumer of motor fuels emitted by different modes of transport in the (the most common type of petroleum products) countries of the European Commonwealth is shown is road transport. The differentiation of pollutants in Table 2 and Table 3,9,10.

Table 2:Number of pollutants emitted by passenger (g/person-km) and freight (g/ton-km) transport

\begin{tabular}{llcccccc}
\hline No & Name & $\mathrm{SO}_{x}$ & $\mathrm{NO}_{x}$ Particulate matter & $\mathrm{CO}$ & $\mathrm{CH}$ & $\mathrm{CO}_{2}$ \\
\hline 1 & Passenger transport: & & & & & & \\
a & Railways & 0.27 & 0.15 & 0.09 & 0.009 & 0.005 & 60.9 \\
b & High-speed railways & 0.16 & 0.09 & 0.05 & 0.005 & 0.003 & 35.8 \\
c & Motor transport & 0.14 & 3.35 & 0.07 & 5.01 & 0.77 & 160.3 \\
d & Air transport & 0.09 & 0.66 & 0.03 & 1.42 & 0.23 & 234.1 \\
2 & Freight transport: & & & & & & \\
a & Railways & - & 0.40 & 0.08 & 0.06 & 0.02 & - \\
b & Motor transport & - & 1.96 & 0.04 & 2.2 & 0.97 & - \\
c & Water transport & - & 0.58 & 0.04 & 0.2 & 0.08 & - \\
\hline
\end{tabular}

Table 3:Structure of air pollution sources

\begin{tabular}{|c|c|c|c|c|c|c|c|}
\hline \multirow[t]{2}{*}{ No } & \multirow[t]{2}{*}{ Source of pollution } & \multicolumn{6}{|c|}{ Share in total emissions, $\%$ vol. } \\
\hline & & USA & GB & Germany & France & Italy & Japan \\
\hline 1 & Industry & 17 & 13 & 35 & 35 & 30 & 40 \\
\hline 2 & Transport & 60 & 60 & 50 & 23 & 25 & 25 \\
\hline 3 & Heat-and-power engineering & 14 & 12 & 12 & 23 & 15 & 20 \\
\hline 4 & Fuel combustion plants & $3-5$ & $1-2$ & $1-3$ & $1-2$ & $2-5$ & $1-2$ \\
\hline 5 & Other & $6-4$ & $14-13$ & 2 & $18-17$ & $28-25$ & $4-3$ \\
\hline
\end{tabular}


As a rule, from all harmful emissions of different vehicles $80-90 \%$ fall on cars, $5-8 \%$ in railways, $1-2 \%$ in air transport and $1 \%$ in water transport (figures may vary for different countries). Despite the constant improvement of engines and a significant reduction in the specific consumption of fuels (almost 2 times), the consumption of motor fuels over the past 20-30 years has increased several fold.

The consequences of air pollution by gas emissions of cars are manifested primarily at the local level. This is due to the fact that motor transport is a specific source of pollution, which is characterized by the following features.

- Low altitude emission of harmful substances, which leads to direct contact and direct effects on the person.

- A relatively low degree of dispersion and removal of harmful substances from the source.

- Greater degree of localization and concentration of pollutants than from other sources.

- The location in areas with a high population density and the degree of concentration of industrial production.

- Multicomponent and high emission toxicity.

- Mobility, which complicates and intensifies the effect of exposure to toxic substances.

- The dependence of the composition of gas emissions not only on the quality of fuel, the operating mode of the engine, but also on the parameters of the environment (air temperature, altitude above sea level).

- $\quad$ The possibility of transforming the components of emissions and the formation of secondary, more toxic products.

It is rather easier to fight against industrial sources of emissions as they are stationary, are characterized by high concentration of harmful substances and the small number of devices by means of which removal of harmful substances to the environment is carried out. It allows to hold more effective measures for reduction and neutralization of emissions, than from numerous mobile sources ${ }^{30-32}$.

As a result, the share of vehicles in pollution of the surface layer of atmospheric air, the most important component of the biosphere, is significantly higher than from other sources. Sources of toxic substances entering the atmospheric air from aggregates and vehicle systems are spent crankcase gases and fuel fumes. The composition of toxic emissions from various sources using petroleum fuels is presented in Table 4.

\begin{tabular}{|c|c|c|c|}
\hline Name & $\begin{array}{c}\text { Carburetor } \\
\text { engines }\end{array}$ & $\begin{array}{c}\text { Diesel } \\
\text { engines }\end{array}$ & $\begin{array}{l}\text { Thermal } \\
\text { stations }\end{array}$ \\
\hline $\mathrm{CO}$ & 40 & 9 & 0,05 \\
\hline $\mathrm{NO}_{x}\left(\right.$ per $\left.\mathrm{NO}_{2}\right)$ & 20 & 33 & 14 \\
\hline $\mathrm{SO}_{\mathrm{x}}($ per S) & 1.5 & 6 & 21 \\
\hline Hydrocarbons (HC) & 24 & 20 & 0.4 \\
\hline Aldehydes, organic acids & 1.4 & 6 & 0.08 \\
\hline Particulate matter (PM) & 2 & 16 & 1.3 \\
\hline
\end{tabular}

The bulk of pollutants (with the exception of sulfur oxides) is emitted when internal combustion engines (ICE) operate. In the exhaust gases of the engine contain more than 200 toxic chemical compounds of these, the following most harmful substances are taken into account:

Carbon monoxide, $\mathrm{CO}$, harmful contaminant contained in the exhaust gases of the engine in the highest concentration.

Hydrocarbons (HC), harmful pollutants and smog-forming substances contained in exhaust gases of the engine and in fuel evaporation of the car.

- $\quad$ Oxides of nitrogen, $\mathrm{NO}_{x}$, harmful pollutants and smog-forming substances contained in the exhaust gases of the engine.

- $\quad$ Oxides of sulfur, harmful pollutants contained in the exhaust gases of the engine.

Solid particles and carbon black (C), harmful polluting suspended particles contained in the exhaust gases of the engine.

Lead compounds, $\mathrm{Pb}$, harmful pollutants contained in engine exhaust gas when using leaded gasoline.

Aldehydes ( $\mathrm{RCHO}$ ), harmful pollutants contained in the exhaust gases of the engine.

Benzo (a) pyrene, a harmful carcinogenic substance contained in the composition of soot in the exhaust gases of the engine. In cities of the CIS, the concentration of benz (a) pyrene in the air is approximately 10 times higher than in England and the USA. The interrelation of atmospheric pollution with 
benz (a) pyrene in large cities with an increasing number of lung cancer diseases is noted.

The composition of the exhaust gases of the internal combustion engine is given in Table 5.

Table 5: Composition of exhaust gases of internal combustion engines, vol. \%

\begin{tabular}{|c|c|c|}
\hline Components & Gasoline engine & Diesel engine \\
\hline Nitrogen & $74-77$ & $76-78$ \\
\hline Oxygen & $0.3-8$ & $2-18$ \\
\hline Water & 3,55 & $0,5-4$ \\
\hline Carbon dioxide & $5-12$ & $1-10$ \\
\hline $\mathrm{CO}$ & $1-10$ & $0.01-0.5$ \\
\hline $\mathrm{NO}_{x}$ & $0.1-0.5$ & $0.001-0.4$ \\
\hline $\mathrm{SO}_{\mathrm{x}}$ & $0-0.002$ & $0-0.03$ \\
\hline Hydrocarbons & $0.01-0,1$ & $0.01-0.5$ \\
\hline Aldehydes & $0-0.2$ & $0-0.009$ \\
\hline Soot, $\mathrm{g} / \mathrm{m}^{3}$ & $0-0.04$ & $0.01-1.1$ \\
\hline Benz(a)pyrene & to 0.00002 & to 0.00001 \\
\hline
\end{tabular}

Except direct negative impact on health of the person, emissions of the motor transport have greenhouse and ozone-depleting effect on the atmosphere of the earth ${ }^{3,4,9,10}$. It is connected with the content in the fulfilled gases of the engine of the following substances.

- $\quad$ Carbon dioxide $\mathrm{CO}_{2}$, the main component in the exhaust gases of the engine, creating a greenhouse effect in the atmosphere (greenhouse gas).

- $\quad$ Methane $\mathrm{CH}_{4}$,

- $\quad$ Ammonia $\mathrm{NH}_{3}$,

- $\quad$ Nitrous oxide $\mathrm{N}_{2} \mathrm{O}$ - greenhouse and ozonedepleting substances contained in the exhaust gases of the engine.

\section{Sulfur Dioxide, Carbon Monoxide, Hydrocarbons}

The sulfur dioxide which is formed at combustion of sulfur-containing fuel already in small concentration creates off-flavor in a mouth and irritates mucosas of a nose, nasopharynx, tracheas and bronchial tubes that is expressed in attacks of dry cough, a hoarseness etc. Single-pass inhalation of very high concentrations of sulfur dioxide leads to short wind and quickly coming disorder of consciousness. Irritation of a mucosa of eyes, cough concentration causes $0.05 \mathrm{mg} / \mathrm{l}$. The most admissible concentration of sulfur dioxide in air of the production enterprises $0.02 \mathrm{mg} / \mathrm{l}$ are considered.

Another, no less dangerous and most mass component of gas emissions of cars is carbon monoxide. Thus, in most large cities of the United States, motor transport accounts for $85-97 \%$ of all carbon monoxide emissions, and its concentration in gas emissions of cars is $7 \%$. The increase in carbon monoxide emissions is observed with a decrease in the excess air ratio, low speed and idling of the engines, an increase in the proportion of heavy fractions in the composition of motor fuels. The extreme toxicity of carbon monoxide, the lack of smell and color make this gas particularly dangerous. The ability to displace oxygen from compounds with hemoglobin is explained by the increased affinity of hemoglobin to carbon monoxide (200300 times greater than to oxygen), resulting in the formation of carboxyhemoglobin. Carbon monoxide affects the nervous and cardiovascular systems. The MAC (MPC) of carbon monoxide in the air of industrial enterprises is $0.0016 \%(0.02 \mathrm{mg} / \mathrm{I})$. With a content of $0.1 \%$ carbon monoxide in the inspired air, death occurs in $30-60$ min with $1 \%$ or more instantaneously.

The most numerous, massive and dangerous components of gas emissions of cars are hydrocarbons, of which there are more than 200: > 32\% are saturated hydrocarbons; 27\% unsaturated hydrocarbons; - up to $4 \%$ - aromatic hydrocarbons; 2\% - aldehydes ${ }^{33-35}$.

Substances that do not belong to aromatic hydrocarbons have an essentially irritating effect on the body, and aromatic hydrocarbons are carcinogens. Hydrocarbons enter the environment as a result of evaporation and incomplete combustion of fuel and during the formation of new compounds during the combustion of fuel. The formation of some of them, for example, polycyclic hydrocarbons, aromatic hydrocarbons, largely depends on the following factors.

- Characteristics and operating mode of engines.

- Volume of consumed fuel.

- $\quad$ Environment parameters.

- $\quad$ The type and quality of fuel used.

- Evaporation and entering the combustion zone of fuels of lubricating oils.

The total emissions of hydrocarbons by road make up a significant part of the pollution in many countries of the world. They account for 
$55-75 \%$ of the total volume of hydrocarbons coming from various sources into the atmosphere.

The special danger to the person and the environment is represented by the lead and its compounds which are contained in gas emissions of cars. Compounds of lead, mainly tetraethyl lead (thermal power plant), add to gasolines for the purpose of increase in octane numbers. Lead and its compounds, getting to an organism, cause the most serious illness (intellectual backwardness, change of behavioural functions of an organism, etc.).

With gas emissions of motor vehicles, 37$85 \%$ of lead and its compounds contained in leaded gasolines enter the atmosphere, and their concentration in emissions is $50-1,000 \mu \mathrm{g} / \mathrm{m}^{3}$. A significant number of these compounds fall into the environment as a result of evaporation of gasolines. The total proportion of lead and carbon monoxide compounds in gas emissions of cars exceeds $75 \% \%^{3,6,7,9}$.

It is also established that when the lead is completely removed, the emissions of hydrocarbons and nitrogen oxides are reduced by $30 \%$. Therefore, the removal of lead from commercial gasoline allowed to advance in solving the problem of environmental pollution and significantly increase the service life of engines.

To assess toxicity (along with the estimate of MAC), is used a concentration index, a dimensionless quantity that takes into account the amount of harmful emissions and the degree of its toxicity. Numerically, the concentration index is equal to the multiplicity of the dilution of exhaust gases (EG) containing the harmful component by air before reaching the MPC.

\section{Nitrogen Oxides}

One of the most common components of gas emissions of motor vehicles are nitrogen oxides. Their share, for example, in large cities of developed countries, accounts for $48-63 \%$ of total emissions from all available sources.

\section{Nitrogen oxides are a particular hazard}

They destroy the ozone layer in the upper atmosphere.

- They have a strong toxic effect on all living things.
They together with hydrocarbons participate in the formation of photochemical smog.

In the presence of nitrogen oxides in the air, the toxicity of carbon monoxide increases, and the norm for its content in the air should be reduced by a factor of 1.5 , since their combined presence aggravates the effect of gases.

According to the degree of toxicological effects on the human body, nitrogen oxides are classified as hazard class 3 (moderately hazardous substances) $)^{3,10}$.

Nitrogen monoxide is a colorless gas, without taste and odor. When inhaled, NO, like CO, binds to hemoglobin, promoting the formation of metahemoglobin and blocking the transport of oxygen from the lungs to the tissues. Nitrogen monoxide is easily oxidized in air (especially at low temperatures) to $\mathrm{NO}_{2}$, a red-brown gas with a pungent odor, the inhalation of which weakens the sense of smell, reduces the ability of the eye to adapt to darkness, and also makes a person more susceptible to pathogens that cause respiratory problems ${ }^{10,36}$.

Combining with atmospheric moisture, $\mathrm{NO}_{x}$ form weak solutions of nitrous and nitric acids, which leads to the precipitation of so-called "acid rain". Under the influence of acid rain, soil acidification and depletion of nutrients, acidification of surface water bodies, degradation and complete destruction of forest areas occur. In addition, nitrogen oxides contribute to an increase in the ozone concentration in the surface layer, and also participate in the formation of photochemical $\mathrm{smog}^{24}$. Acidic oxides in the ground layer of air are strong oxidants, adversely affecting the respiratory system of living organisms and plant growth, causing acid rain. Thus, the annual damage to US agriculture from increased concentrations of oxides is estimated at $\$ 1.9-4.3$ billion. Approx. $30 \%$ of the acid rains in UK is due nitric acid presence in them. Therefore, in the majority of developed countries, the emissions of the such substances are limited and strictly monitored for their reduction ${ }^{37}$.

Reduction of nitrogen oxide emissions is achieved mainly by improving the design of combustion chambers, reducing the compression ratio and the excess air factor, optimizing the 
composition of the fuel by reducing the content of aromatic compounds.

Nitrogen oxides are present in the composition of exhaust gases in the form of oxide and nitrogen dioxide. They are formed as a result of a reaction between atmospheric nitrogen and oxygen or water vapor at a high pressure (28-35 atm) and a temperature of $540-650^{\circ} \mathrm{C}$ during each compression in the cylinders. The fuel does not participate directly in this reaction. Oxides of nitrogen are very toxic. In the most typical cases, poisoning with nitrogen oxides begins with a slight cough, which after a while passes. At relatively high concentrations, irritation of the respiratory tract increases: a strong cough, sometimes headache, vomiting, etc. When poisoning with nitrogen oxide, in addition to general symptoms, dizziness and weakness are noted, the face pales, blood pressure decreases. After inhalation for 6-8 $\mathrm{min}$ of air containing approximately $6 \mathrm{mg} / \mathrm{l} \mathrm{of}$ nitrogen oxide and $3 \mathrm{mg} / \mathrm{l}$ for $12 \mathrm{~min}$ death occurs. Poisoning with nitrogen dioxide is characterized by pulmonary edema followed by bronchopneumonia. A lethal concentration of $0.1 \mathrm{mg} / \mathrm{l}$ when inhaled for an hour. MAC (MPC) of nitrogen oxides in the air of industrial enterprises is $0.005 \mathrm{mg} / \mathrm{l}$. Under certain weather conditions, a photochemical reaction is possible, which contributes to the formation of nitrogen oxide substances that damage the mucous membrane of the eyes, as well as plants and even rubber. According to American researchers, the maximum content of nitrogen oxides in the atmosphere is (in terms of nitrogen dioxide) $0.025 \mathrm{mg}$ by volume.

Nitrogen oxides by action on the human body are the most toxic components of exhaust gases, and their neutralization by catalytic decomposition or reduction becomes especially important.

The main contribution to the formation of nitrogen oxides is made by high-temperature processes $\left(T>1,100^{\circ} \mathrm{C}\right)$ of air nitrogen oxidation according to the mechanism of Ya. B. Zel'dovich ("thermal" $\mathrm{NO}_{x}$ ), reactions (1)-(2) ${ }^{11}$. According to this mechanism, $\mathrm{O}_{2}$ dissociates into atoms at high temperatures and interacts with $\mathrm{N}_{2}$ in accordance with the following reversible chain reactions ${ }^{38}$.

$$
\begin{aligned}
& \mathrm{O}+\mathrm{N}_{2} \leftrightarrow \mathrm{NO}+\mathrm{N} \\
& \mathrm{N}+\mathrm{O}_{2} \leftrightarrow \mathrm{NO}+\mathrm{O}
\end{aligned}
$$

The share of "thermal" $\mathrm{NO}_{x}$ is approximately $20-40 \%$ (depending on the type of fuel) of the total amount of nitrogen oxides emitted annually to the atmosphere, the rest being "fast" and "fuel" $\mathrm{NO}_{x}$.

Reactions involving hydrocarbon constituents also play an important role in the formation of $\mathrm{NO}$ ("fast" $\left.\mathrm{NO}_{x}\right)^{39}$. $\mathrm{CH}$ radicals existing in the flame front can react with atmospheric nitrogen to form cyanic acid, which in turn reacts according to the scheme.

$$
\begin{aligned}
& \mathrm{CH}+\mathrm{N}_{2} \leftrightarrow \mathrm{HCN}+\mathrm{N} \\
& \mathrm{N}+\mathrm{OH} \leftrightarrow \mathrm{H}+\mathrm{NO}
\end{aligned}
$$

Unlike "thermal", "fast" $\mathrm{NO}_{x}$ can form at lower temperatures $\left(\sim 700^{\circ} \mathrm{C}\right)^{24}$.

Annually in the atmospheric air about 180 million tons of nitrogen oxides are emitted ${ }^{40}$. Approximately 120 million tons of $\mathrm{NO}_{\mathrm{x}}$ are formed naturally (forest fires, vital activity of soil bacteria, volcanic activity, lightning discharges, etc.) and are evenly distributed throughout the globe. Background concentrations of $\mathrm{NO}_{2}$ over continents range from 0.4 to $9.4 \mu \mathrm{g} / \mathrm{m}^{3}$, and for NO they range ${ }^{37}$ from 0 to $7.4 \mu \mathrm{g} / \mathrm{m}^{3}$.

The source of NO can be not only atmospheric $\mathrm{N}_{2}$, but also nitrogen, which is part of the fuel components ("fuel" $\mathrm{NO}_{\mathrm{x}}$ ). The mechanism of formation of nitrogen monoxide from bound nitrogen is presented in Fig. 110, ${ }^{41}$. According to this scheme, the formation of $\mathrm{NO}$ is preceded by the conversion of fuel nitrogen to ammonia and cyanic hydrogen acid.

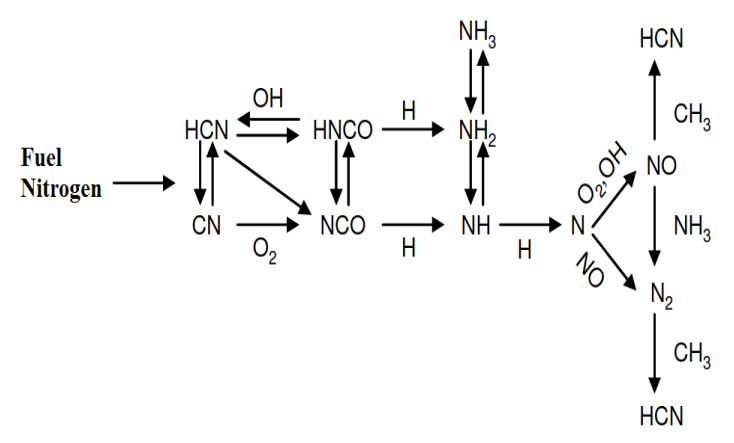

Fig.1. Mechanism of NO production from fuel nitrogen ${ }^{41}$

Unlike naturally occurring nitrogen oxides, anthropogenic emissions (60 million tons of $\mathrm{NO}_{x}$ per year 40) are concentrated mainly in the areas of human economic activity. In this regard, the 
concentration of $\mathrm{NO}_{\mathrm{x}}$ in large settlements is usually several times higher than the natural background values.

\section{The main anthropogenic sources of nitrogen} oxides are.

- Transport.

- $\quad$ Power plants.

- Nitric acid production.

- $\quad$ Explosives.

- $\quad$ Fertilizers.

- $\quad$ Agriculture, etc.

Among the anthropogenic sources, motor transport contributes most to the pollution of atmospheric air with nitrogen oxides ${ }^{42}$. Such a high figure is primarily associated with the constant expansion of the world's automobile fleet, which today has about 1.5 billion units, and by 2030 could reach 2.7 billion units ${ }^{43}$. This is evidenced by the statistics: for the last 15 years, sales of cars have grown by $40.5 \%$ (from 51.55 million in 2000 to 72.41 million in 2015) ${ }^{44}$.

The exhaust gases of vehicles, depending on the type of engine (two- or four-stroke, gasoline or diesel), operating conditions, the speed they develop, etc. on the average contain from 11 to $13 \mathrm{~g} \mathrm{NO}_{\mathrm{x}}$ per 1 liter of fuel (Table 6) $)^{40,45}$. Thus, the average car with an annual mileage of 16.7 thousand $\mathrm{km}^{25}$ and a fuel consumption of 10 liters for every $100 \mathrm{~km}$ of the path emits about $20 \mathrm{~kg}$ of $\mathrm{NO}_{x}$ into the atmosphere.

$\mathrm{NO}, \mathrm{NO}_{2}^{3,7,10}$.

Table 6: Compositions of exhaust gasoline and diesel engines (in the absence of a catalyst)

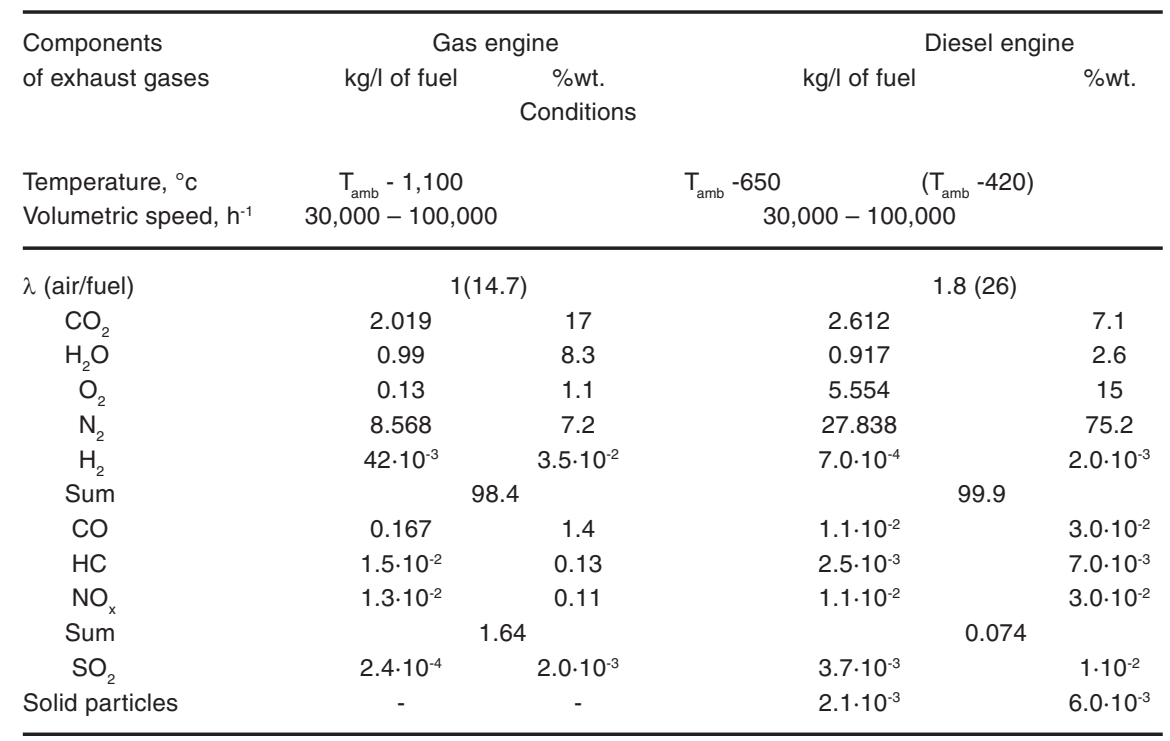

Note: $\mathrm{T}_{\mathrm{amb}}$ - Ambient temperature, ${ }^{\circ} \mathrm{C} ; \lambda$ - coefficient of air excess, expressing the ratio between the actual and theoretically necessary amount of air.

The emission standards for nitrogen oxides applied to road transport were first introduced in the European Union in 1992 (Euro-1).

Despite the fact that modern automotive technologies can significantly reduce nitrogen oxide emissions by improving the engine design and its optimal adjustment, the $\mathrm{NO}_{x}$ level still exceeds the legal norms ${ }^{26}$. For this reason, an increasingly urgent task is the development of new methods for additional purification. Since the reduction of nitrogen oxides to an environmen friendly molecular nitrogen is a thermodynamically advantageous process, cleaning the car's exhaust gases is essentially a kinetic problem, and therefore the main method of neutralizing $\mathrm{NO}_{x}$ is the installation of catalytic systems $^{27,28}$. The choice of catalyst depends directly on the air/fuel ratio, the composition and temperature of the off-gases, and therefore the catalytic purification schemes for cars with petrol and diesel engines differ significantly from each other.

\section{Air pollution in Almaty}

In Kazakhstan, on a national scale, 
the share of motor vehicles in total emissions of pollutants into the atmosphere by all technogenic sources reaches on average $40 \%$, in the mass of industrial waste $-2 \%$. The southern capital of the Republic of Kazakhstan, Almaty, is a very unique city by its physico-geographical and natural climatic characteristics. Almaty is located in the north of the mountain spurs of the Tien Shan mountain system, at the northern foot of the Zailiysky Alatau, on the cones of the Ul'ken (Big) interfluve between Almaty and Kishi (Malaya) of Almaty. In Almaty, the natural zones of the severe north and hot south are interbreeding ${ }^{3,46-50}$. The complex terrain and climatic features create unfavorable conditions for the dispersion of impurities from low emission sources, as a result of which harmful substances accumulate in high concentrations, which then take part in the formation of smog phenomena.

The most polluted environment in Almaty, according to the Center for Monitoring the Environment, is the city's atmospheric air (Fig.2). The main source of atmospheric air pollution in Almaty is motor transport. As a result, in the atmospheric air of Almaty, an increased content of formaldehyde, nitrogen dioxide, phenols, carbon monoxide was noted. The most disadvantaged areas of the city are areas of CHP-1, highway along the avenue Raiymbek District canning factory.

The main reason for such high and persistent pollution of the atmosphere are climatic conditions of Almaty city that are unfavorable from the point of view of atmospheric pollution. These include, first of all, weak wind currents (average annual wind speed of $1.7 \mathrm{~m} / \mathrm{sec}$.) and a powerful temperature inversion that contribute to the accumulation of harmful components in the city's atmosphere. Due to the disadvantageous location of the city in the alignment of the Almaty gorge, cold air draining from the mountains at night, stagnates in the streets and squares, causes stable temperature inversions in the winter for several days. In the cold period of the year, the concentration of dust, soot and carbon monoxide in the morning and evening hours is higher than in the daytime, which is due to the presence of surface inversions during these periods. The concentration of nitrogen dioxide is higher in daytime (12 hours) and evening (18 hours) and is associated with the most intensive traffic. The concentration of sulfur dioxide increases by the end of the day. In the warm season, the concentration of all impurities is less than in the cold season, with a decrease towards the end of the day $3,7,15$.

In Almaty the amount of harmful emissions into the atmosphere is more than 200,000 tons per year, of which about $75 \%$ is motor transport (more than $80 \%$ of emissions in the atmosphere of the city are the share of motor transport, about $12 \%$ - of heat supply facilities). Almaty's atmosphere is heavily polluted, and the concentration of impurities in a number of components far exceeds the MAC. The main harmful impurities in the air are dust, soot, carbon monoxide, nitrogen oxides, etc. In the Almaty air there is nitrogen dioxide, which is formed when fuel is burnt at very high temperatures and excess oxygen. The main sources are automobile exhaust fumes, CHP emissions, solid waste incineration and gas combustion. Among some highways in the air, among other hydrocarbons, especially a lot of pentane was found (up to $4.5 \mathrm{mg} / \mathrm{m}^{3}$ ). At high concentrations, they have a strong narcotic effect. In low concentrations, methane hydrocarbons lower blood pressure ${ }^{50}$.

Comparison of data on atmospheric pollution in Almaty with concentrations of harmful impurities in other cities shows that Almaty is one of the most polluted cities in the CIS. Almaty is the most populous city in Kazakhstan with a large number of cars and heavy traffic, which inevitably complicates the ecological situation. Almaty belongs to the cities of Kazakhstan with a systematically long-term high level of air pollution. Despite the decrease in emissions of harmful substances into the atmosphere from stationary sources, there is no fundamental improvement in the state of the atmospheric air in Almaty. Consequently, the increase in emissions of pollutants is directly related to the increase in the number of vehicles, with difficulties in ensuring effective traffic through the city streets, with traffic jams that have appeared. 


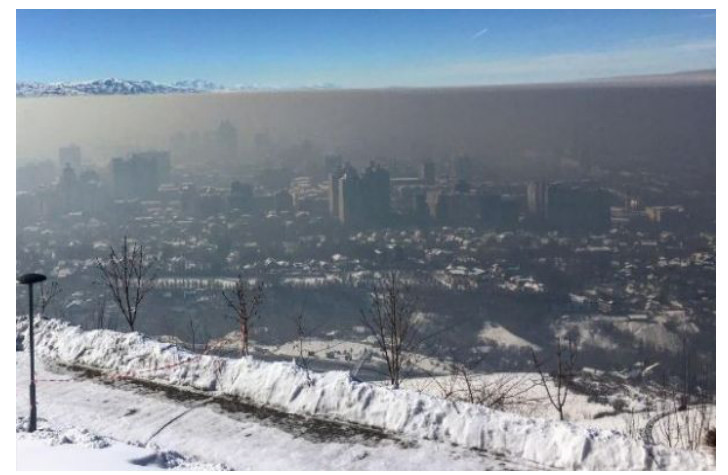

Fig. 2. Smog in Almaty ${ }^{48}$

So, being one of the most beautiful cities of our country, Almaty remains one of the most disfunctional in the ecological plan.

Purification of exhaust gases of vehicles. Catalysts on the metal and ceramic blocks

The methods used to reduce the toxicity of exhaust gases from spark-ignition engines fall into two main categories.

\section{1) Design methods \\ 2) Exhaust gas purification}

The known methods for reducing the toxicity of exhaust gases can be represented in the form of the following scheme (Figure 3).

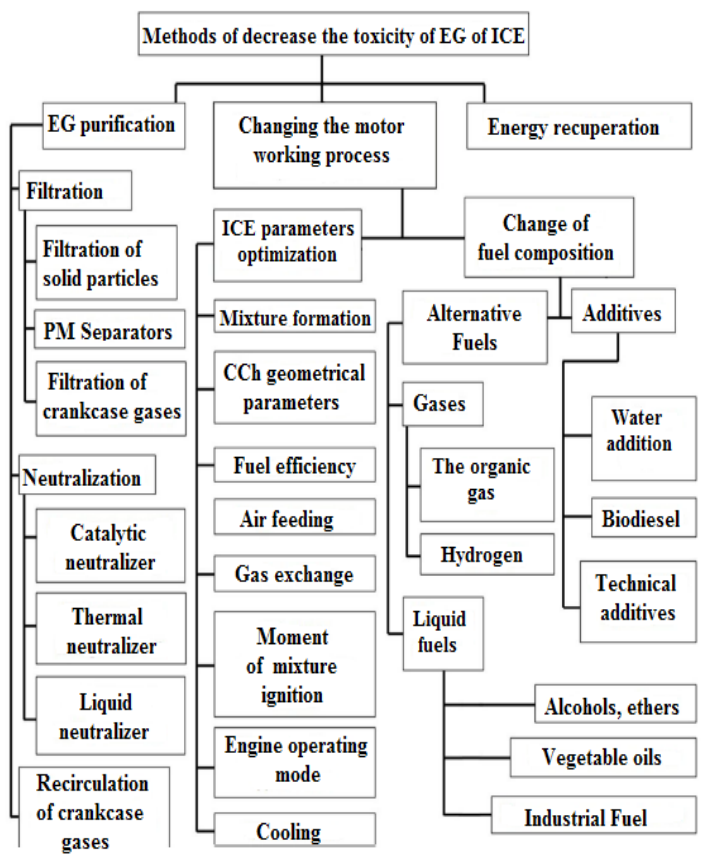

Fig. 3. Methods for reducing the toxicity of exhaust gases $(E G)$ from internal combustion engines (ICE) ${ }^{51}$
Monolithic blocks are the most suitable carriers of the catalysts used for the solution of environmental problems thanks to their developed surface, a low pressure drop, high thermal and mechanical stability, ease of an arrangement in the reactor and a possibility of their use as a substrate for a secondary catalyst carrier (a washcoat). The most acceptable way of production of the washcoat with an advanced surface is the chemical method of applying the carrier from solution. This method allows to prepare solutions of any consistence with introduction into solution of any thermo stabilizing additives and promoters. Impregnation method is very simple in technological performance and does not require special equipment. For example, it is convenient to prepare a washcoat in a ball, a porcelain mill. Homogeneous slurry is obtained with a particle size less than 10 microns.

Thus researchers of Kazakhstan more than 50 years have been creating and investigating (Fig. 4) efficient catalysts on the metal block carriers for exhaust purification ${ }^{3,13-16,19-23,29,33,35,52-59}$.

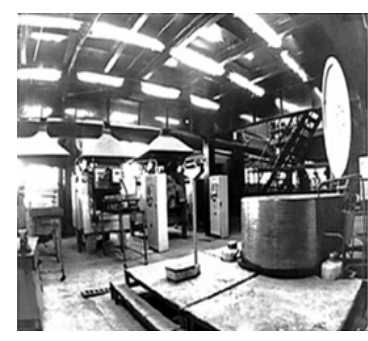

(a)

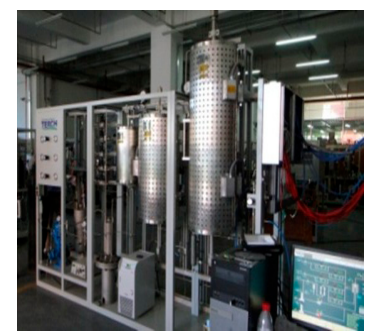

(c)

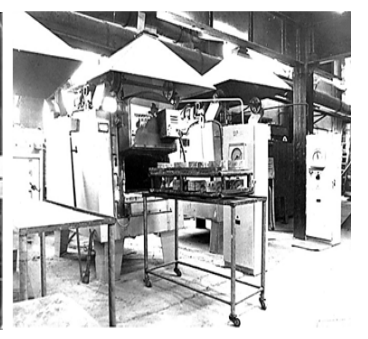

(b)

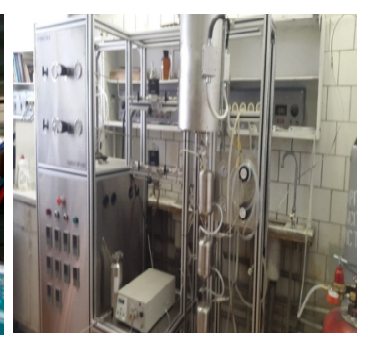

(d)
Fig. 4. Equipment for preparation of metal block catalysts (a-centrifuge, b-furnaces for roasting of catalysts) and flow installations for researches of catalytic gas purification $(c, d)$

As a rule, as the carrier in the catalyst serves the ceramics providing its mechanical durability. Neutralizer-converter is set in system of release to the muffler or instead of it. In the case from stainless steel the carrier block with numerous longitudinal channels - pores on which walls the special substrate of 20-60 microns thick with the developed microrelief (rough) is applied (support as washcoat) settles down. 
Depending on the conditions of use, the monolithic structures are made either of porous cordierite ceramics $\left(2 \mathrm{MgO} \cdot 2 \mathrm{Al}_{2} \mathrm{O}_{3} \cdot 5 \mathrm{SiO}_{2}{ }_{2}^{27}\right)$ or of stainless steel and coated with a layer $(30-50 \mu \mathrm{m})$ of a porous carrier with a developed surface area (Fig.5-7). The composition of such a carrier, as a rule, is $\mathrm{Al}_{2} \mathrm{O}_{3}$; or $70-85$ wt. $\% \gamma-\mathrm{Al}_{2} \mathrm{O}_{3}$ and $10-30$ wt. $\% \mathrm{CeO}_{2}, \mathrm{La}_{2} \mathrm{O}_{3}$ or $\mathrm{BaO}$. As a carrier in some cases $\mathrm{CexOy-}-\mathrm{ZrO}_{2}$ is also used. It allows to increase as much as possible the effective area of contact of a catalytic covering with exhaust gases - up to the sizes about $20,000 \mathrm{~m}^{2}$, and the weight of the precious metals applied on a substrate on this huge square constitutes only 2-3 g. The ceramics is made rather fire-resistant - maintains temperature to $800-850^{\circ} \mathrm{C}$.

As carriers of a catalytic layer metal is often used. So, for example, as the metal carrier take an aluminum, steel and titanic foil, oxidize it and obtain an oxide film on metal. The foil is rolled and the active layer is applied on it. It allows to increase the area of a working surface, to obtain smaller counter-pressure, to accelerate a heating of catalytic converter up to the working temperature. For example, in ${ }^{13,14,29,33}$, $54,5,60,61$ for preparation of catalysts on the metal block carriers the heat-resistant foil has been applied.

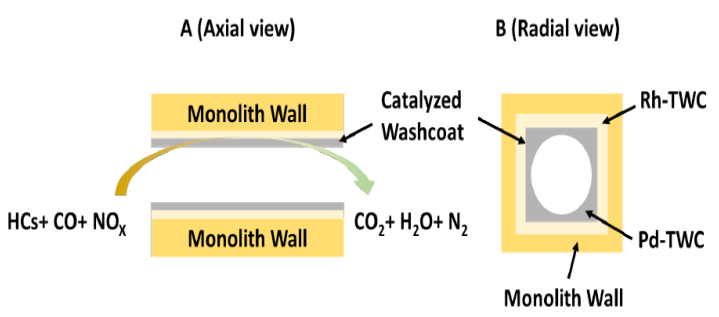

Fig. 5. A washcoated monolith automotive three-way-catalyst ${ }^{62}$

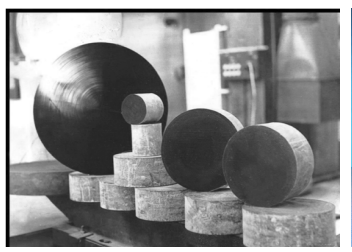

(a)

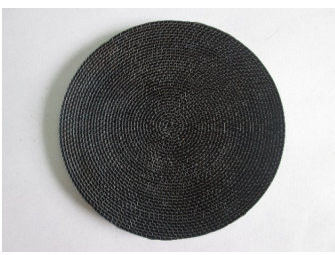

(c)

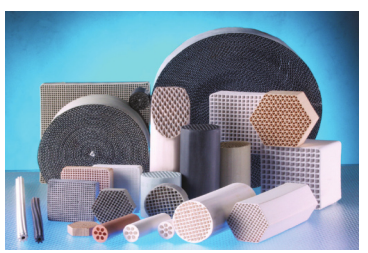

(b)

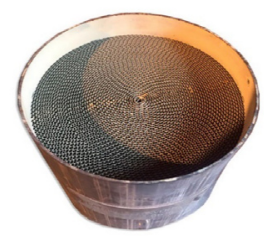

(d)
Fig. 6. Images of catalysts on the metal block carrier: $a, b-$ perspective view ${ }^{2,3}$, where (b) - catalysts on block carriers of Redkino catalyst company (Russia), c- cross-sectional view, c- ready-to-use block ${ }^{4}$
Block carrier on the base of ceramic (Fig.7) is a highly porous cellular ceramic material with a mesh-cellular maze-arch structure, which has a number of distinctive advantages. The surface of the cellular carrier develops by applying a substrate on which the active component is applied. Group VIII metals and their mixtures with promoters are used as the active ingredient. The use of highly porous ceramic honeycomb block catalysts makes it possible to carry out the process in the liquid phase at sufficiently high rates due to the high degree of mixing and dispersion.

Ceramic monoliths with a thin wall (0.01$0.02 \mathrm{~cm})$, low density $(220-280 \mathrm{~g} / \mathrm{l})$ and a high geometric surface, facilitating the ignition of the catalyst after the start have been developed and used. The use of a perforated foil allows the gas from one channel of the monolith to pass into the adjacent one, which improves the use of the volume of TWC and provides a more uniform flow.

Catalysts based on highly porous cellular materials for the neutralization of waste gases are developed relatively recently. In block-cellular catalysts produced in one of the leading centers for the development of highly porous mesh materials (Perm region, Russia), the issue of improving the adhesion of $\gamma-\mathrm{Al}_{2} \mathrm{O}_{3}$ to the surface of a nichrome carrier is solved by the replacement of $\mathrm{Cr}^{3+}$ ions by $\mathrm{A}^{13+}$ ions. The catalytic layer is formed from highly dispersed platinum in an atmosphere of hydrogen ${ }^{63}$. Such catalysts with different active coatings are used in ecological catalysis for oxidation of organic compounds, carbon monoxide and reduction of nitrogen oxides during neutralization of exhaust gases of internal combustion engines ${ }^{63-65}$ and in waste gases of thermal power plants ${ }^{63,64}$.

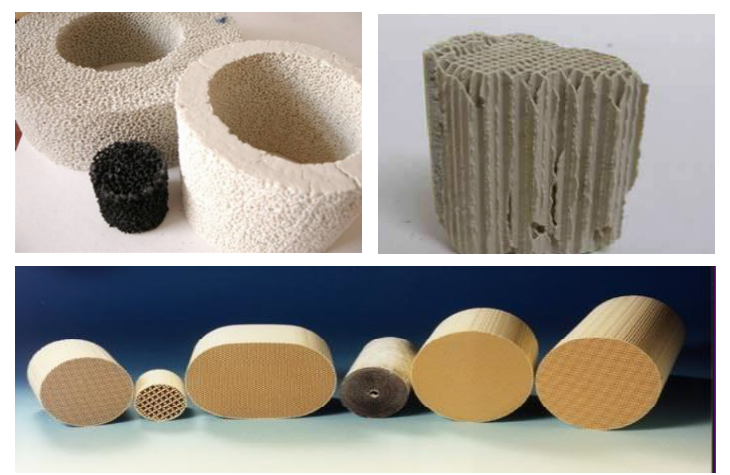

Fig. 7. General view of ceramic block carriers ${ }^{66}$ 
Metal High Porous Cellular Materials (MHPCM) are obtained by duplicating the primary polymer matrix using powder metallurgy technologies or by electrochemical deposition ${ }^{63}$. Ceramic carriers have higher thermal stability and chemical resistance in corrosive media, high specific surface, lower cost of the material itself and manufacturing of products (honeycomb). The problem of weak adhesion of an intermediate active layer based on $\gamma$-alumina with a metal surface is solved in the course of a simple process of sintering it with a primary ceramic matrix. Catalysts on ceramic carriers of honeycomb structure are obtained by the method of continuous plastic pressing through spinnerets, followed by drying and sintering. The channels in the honeycomb block catalyst are through-pass and have the same hydraulic diameter over their entire height. In some countries, honeycomb ceramic catalysts on cordierite, as a rule, carriers with an intermediate substrate (alumina and cerium oxides) and an active metal $(\mathrm{Pd}, \mathrm{Pt}, \mathrm{Rh})$ are widely and successfully used for purification of waste gases from combustion products in engines of various types ${ }^{63-65}$. Russian producers of catalysts use, in the main, imported cordierite blocks, for example, Rauschert (Germany), containing 400 longitudinal channels per $1 \mathrm{sq}$. km. inch.

As modern carriers of such catalysts, metal or ceramic highly porous honeycomb or cellular materials are used. The latter are most effective from the point of view of completeness and uniformity of the course of oxidation-reduction processes of detoxification along the section of the gas stream to be purified. The active component in such catalytic systems are both noble metals and transition metal oxides: oxides of copper, silver, manganese and their mixtures with other d-elements. Various natural aluminosilicates, cordierite, electrophorphone and other types of oxide and other types ceramics can be used as the material of the ceramic frame ${ }^{63}$. Of the various methods for synthesizing ceramic MHPCM (or foam ceramics), in practice, slurry technology is applied, using a variety of burn-in additives. Its essence consists in the thermal destruction of the workpiece impregnated with ceramic slurry from the open-celled polyurethane foam and subsequent sintering of the components of the slip at high temperature with the formation of a strong skeleton. The obtained ceramic cellular material is a kind of replica of the structure-forming polymer matrix. Different effective catalysts for the gas-phase processes have been created ${ }^{63}$.

During last years the works of the D. Mendeleev University of Chemical Technology (Russia) are aimed at the creation of effective multicomponent catalyst compositions of complex composition such as $\mathrm{Au} / \mathrm{Ce}_{0.72} \mathrm{Zr}_{0.18} \mathrm{Pr}_{0.1} \mathrm{O}_{2}$ or $\mathrm{Me}_{0.1} \mathrm{Zr}_{0.18} \mathrm{Ce}_{0.72} \mathrm{O}_{2}$, where $\mathrm{Me}$ is the rare earth metal and methods for their application to ceramic honeycomb carriers. This trend corresponds to trends in world practice ${ }^{63-65}$. They created a method for the synthesis of a cerium-containing catalyst, comprising $20-50 \%$ by wt. of cerium dioxide, $15-35 \%$ by wt. of zirconia, and the remainder - oxides of rare earth elements is considered. The compound was prepared by co-precipitation of metal hydroxides in an aqueous medium with ammonium hydroxide. To purify carbon monoxide and organic derivatives in the presence of nitrogen oxides, the authors of ${ }^{68}$ proposed a multicomponent solid solution with the spinel structure $\mathrm{AB}_{2} \mathrm{O}_{4}$, where $\mathrm{A}$ is $\mathrm{Zn}_{0.18-0.21} \mathrm{Cd}_{0.18 \text { - }}$ ${ }_{0.21} \mathrm{Co}_{0.18-0.63} \mathrm{Fe}_{0,02-0.46}$ and $\mathrm{B}$ is $\mathrm{Cu}_{0.09-0.36} \mathrm{Ni}_{0.09-0.11} \mathrm{Cr}_{0.24-}$ ${ }_{0.48} \mathrm{Fe}_{0.28-0.34}$. Complete detoxification occurs at temperatures of $460-560^{\circ} \mathrm{C}$. The catalyst has a high thermal stability.

The analysis of patents ${ }^{3}$ shows that the most advanced catalysts for neutralizing gas emissions of vehicles are systems containing cerium dioxide. Additions of oxides of lanthanum, europium, zirconium; and also a mixture of oxides of rare earth elements (REE) is introduced into the structure of $\mathrm{CeO}_{2}$ in order to improve the catalytic properties and thermal stability.

Based on analysis of the literature and patent sources with ceramic compositions highly porous cellular materials (HPCM) on the basis of corundum $\left(\alpha-\mathrm{Al}_{2} \mathrm{O}_{3}\right)$ and high-alumina porcelain mass were proposed ${ }^{63-65,69,70}$. Ceramic highly porous cellular materials were obtained by reproducing the reticulated cellular framework of a polymer matrix of open-celled polyurethane foam, the essence of which consists in thermal degradation of a polymer matrix impregnated with a ceramic slurry and subsequent sintering of the slip components at high temperature to form a strong framework. The resulting ceramic cellular material is a kind of replica of the structure-forming polymer matrix. The 
characteristic microphotographs of the cell and the HPCM jumpers are shown in Fig.8. Elastic fine-pored polyurethane foams (EFNPF) with a pore density of $20 \mathrm{ppi}$ (cell size $=1.5-2.0 \mathrm{~mm}$ ) were used to form the reticular-cellular structure of HPCM as the structureforming matrix.

The main components of the typical composition of the ceramic slip are.

- $\quad$ A dispersed phase (inert filler).

- A basic binder.

- $\quad$ Sintering (sometimes simultaneously lowering the sintering temperature) additives.

- $\quad$ A temporary technological binder.

As the dispersed phase of the slip on the basis of $\alpha-\mathrm{Al}_{2} \mathrm{O}_{3}$, electrically melted corundum was used, as polyvinyl alcohol as an adhesive (a temporary technological bundle). The use as a main component of the suspension for the manufacture of cellular corundum materials is due to its properties: inertness, high mechanical strength, chemical resistance, heat resistance and wear resistance ${ }^{71}$.

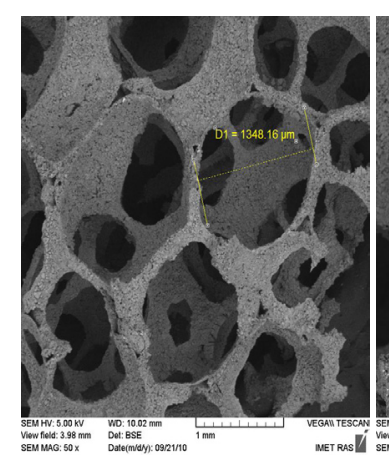

(a)

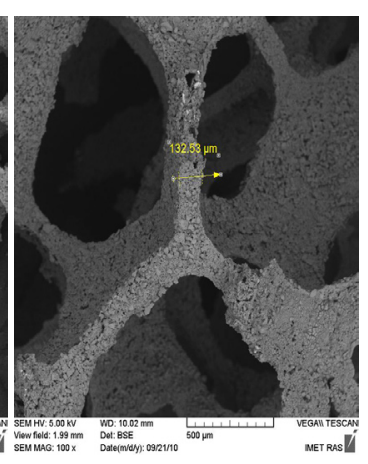

(b)
Fig. 8. SEM images of the cellular structure of HPCM: a - a general view of the honeycomb frame structure, $b$ - $a$ jumper

To reduce the sintering temperature from 1,700 to $1,550^{\circ} \mathrm{C}$, while maintaining the necessary strength properties, a special technological additive in the form of magnesium and titanium oxides $\left(\mathrm{TiO}_{2}+\mathrm{Mg}_{2}(\mathrm{OH})_{2} \mathrm{CO}_{3}\right)$ was introduced into the composition of the charge. $5 \%$ solution of polyvinyl alcohol (PVA) was used as a temporary technological bundle (TTB). The introduction of a ceramic slurry of adhesives promotes the formation of a film on the surface of an organic foam that burns together without residue with the matrix material and creates a micro-fractured structure of the HPCM jumpers.
The impregnation of the preforms was performed by immersing the polyurethane polymer matrices in the forming ceramic slurry using a mechanical impact (cycle: compression, expansion) to its uniform distribution throughout the volume of the preform. Excess slip was removed by pressing each blank with rollers and perforated plates. The appearance of the blanks of polyurethane foams and HPCM samples is shown in Figure 9.

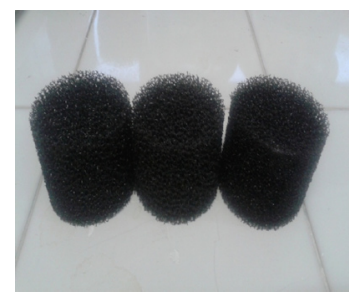

(a)

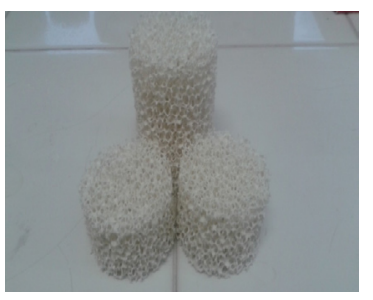

(b)
Fig. 9. A blank of polyurethane foams 20 ppi (a), a sample of HPCM (b)

The samples of ceramic highly porous block-cellular materials and carriers based on direct synthesis have characteristics allowing to use them for further application of compositions based on REE and noble metals catalytically active in the process of detoxification of exhaust gases of industry and vehicles. The ceramic frame material provides sufficient mechanical strength and chemical resistance for the operating conditions, as well as optimal hydrodynamic conditions for catalytic reactions. The selected active $\gamma-\mathrm{Al}_{2} \mathrm{O}_{3}$ support provides a high specific surface area for future catalysts.

One of the disadvantages of catalysts on metal block carriers is the low adhesion of the metal surface to the coating containing the active layer. Ceramic monoliths are widely used for TWC, but in some situations it is more advantageous to use stainless steel foil for applying TWC. Despite the obvious positive aspects when using ceramic carriers, it is nevertheless more advantageous in some cases to use carriers based on metal foil. When compared with a catalyst on a ceramic carrier, the metal supported catalyst (MSC) has several advantages $^{72-74}$, in particular.

The high strength of the metal and the high machinability make it possible to fabricate the carrier walls sufficiently thin that as a result provides a general significant increase in the 
geometric area of the metal substrate.

- The process of chemical reaction occurs on the catalytic surface.

The overall increase in area is an incomparable advantage, which leads to a significant improvement in the catalytic effect: this condition allows to reduce the total volume of the cylindrical substrate by $20 \%$ in comparison with the traditional method while maintaining the efficiency of operation.

- The increased mechanical strength of the base allows to eliminate the insulating gasket between the casing and the substrate and thereby reduce the diameter of the casing by $15 \%$.

- $\quad$ These factors reduce the total weight of the neutralizer by one third compared to the neutralizer on the ceramic substrate while maintaining the catalytic effect (Table 7$)^{72,74}$.

Table 7:Comparative characteristics of metallic and ceramic carriers

\begin{tabular}{lcc}
\hline Characteristics & $\begin{array}{c}\text { A metallic carrier, } \\
77 \text { cells } / \mathrm{cm}^{2}\end{array}$ & $\begin{array}{c}\text { A ceramic carrier, } \\
62 \text { cells } / \mathrm{cm}^{2}\end{array}$ \\
\hline $\begin{array}{l}\text { Wall thickness without } \\
\text { coating }(\mathrm{mm})\end{array}$ & 0.04 & 0.15 \\
Geometric area $\left(\mathrm{m}^{2} / \mathrm{dm}^{3}\right)$ & 3.7 & 2.8 \\
Effective uncoated & 91 & 77 \\
cross-section $(\%)$ & & \\
\hline
\end{tabular}

Due to the small thickness, the structure of the metal substrate can be designed in such a way that the effective cross-section is much higher than using a ceramic material: a noticeable reduction in hydraulic resistance is also achieved. Also, the higher melting point of chromium-aluminum steel (above $1,500^{\circ} \mathrm{C}$ ), while the softening temperature of cordierite is close to $1,300^{\circ} \mathrm{C}$, should be attributed to the number of advantages of metallic carriers when compared with the most widespread Cordierite blocks of Corning Glass. Differences in the thermophysical properties of metallic and ceramic carriers are also important. Thus, for the heating of the metal support to operating temperatures it requires only half the heat required to heat the ceramic block of similar dimensions. Because of the low thermal capacity of the metal the catalyst on the metal carrier comes to operating mode at start of the cold engine much quicker. A characteristic index for ceramic materials, in contrast to metals, is their low thermal conductivity. At low temperatures, steel has a 14 times higher thermal conductivity than ceramics, at high temperatures this figure reaches 20 $(\text { Table } 8)^{75}$. The indicator in a greater degree reduces the time of heating of the neutralizer on a metal base.

The effective use of metals in the active phase in the preparation of catalysts on metallic supports is achieved by the fact that the active phase is converted to a highly dispersed state. In this case, most of the surface of the catalyst is available for the reacting substances and the metal particles have specific adsorption and catalytic properties. In connection with this, the process of regulating the nucleation and further growth of metallic particles during the preparation of catalysts is of practical interest.

Table 8: Comparison of physical characteristics of metallic and ceramic carriers

\begin{tabular}{lcc}
\hline Conditions & \multicolumn{2}{c}{$\begin{array}{c}\text { Specific heat conductivity } \\
(\mathrm{W} / \mathrm{mK})\end{array}$} \\
& $\begin{array}{c}\text { Metal carrier } \\
\text { Ceramic carrier }\end{array}$ & Cer \\
\hline $20^{\circ} \mathrm{C}$ & 14 & 1 \\
$600^{\circ} \mathrm{C}$ & 20 & 0.8 \\
Specific heat, $\mathrm{kJ} / \mathrm{kg}, 0-100^{\circ} \mathrm{C}$ & 0.5 & 1.05 \\
\hline
\end{tabular}

Modern neutralizers, developed, for example by Ukrainian scientists, provide for a multistage technology ${ }^{76}$ for cleaning the exhaust gas engine, consisting of:

1) Particulate filters from synthetic cordierite honeycomb structure with a formed catalytic coating in the form of complex oxides of copper, chromium, cobalt, deposited on aluminum oxide.

2) Effective catalysts for three-routing transformations $\left(\mathrm{CO} / \mathrm{C}_{\mathrm{n}} \mathrm{H}_{\mathrm{m}} / \mathrm{NO}_{\mathrm{x}}\right)-(\mathrm{Pd}, \mathrm{Pt}$, $\mathrm{Rh})$-REE (La, Ce) $/ \gamma-\mathrm{Al}_{2} \mathrm{O}_{3} /$ cordierite.

3) Neutralizers developed on the basis of processes of selective reduction of nitrogen oxides (I, II) on structured catalysts using reductants of different chemical nature: ammonia, vanadium-titanium and oxide compositions ( $\mathrm{Cu}, \mathrm{Fe}, \mathrm{Cr} / \mathrm{Al}_{2} \mathrm{O}_{3}$ ), $\mathrm{C}_{1}-\mathrm{C}_{4}$ hydrocarbons and carbon monoxide $(\mathrm{CoO} /$ ( $\left.\mathrm{HZSM}-5 / \mathrm{Al}_{2} \mathrm{O}_{3}\right) /$ cordierite, $\mathrm{CoO} / \mathrm{ZrO}_{2} /$ caolinaerosil, $\mathrm{Pd} / \mathrm{Co}_{3} \mathrm{O}_{4} / \mathrm{CeO}_{2} /$ cordierite).

The authors developed block (monolithic) catalysts of the honeycomb structure for cleaning industrial gas emissions and vehicles from $\mathrm{CO}, \mathrm{NO}_{x}, \mathrm{C}_{n} \mathrm{H}_{m}$.

$\ln ^{77-83}$ authors carried out experimental investigations using Heated Catalytic Converter (HCC) in combination with the Light Off Converter (LOC). 
The following conclusions were received

- $\quad$ HCC in combination with the HCC and LOC tested on a SI engine significantly increases the temperature of the main catalytic converter to reduce cold-start $\mathrm{HC}$ and $\mathrm{CO}$ emissions.

- $\quad$ HCC and LOC configuration are successful, because they quickly initiate the catalytic reaction.

- $\quad$ There is significant reduction in $\mathrm{CO}$ and $\mathrm{HC}$ emission by the use of Thermal Reactor with heated air injection.

- The Thermal Reactor with $120 \mathrm{lpm}$ heated air injection gives maximum reduction of $\mathrm{CO}$ and with $100 \mathrm{lpm}$ heated air injection gives maximum reduction of $\mathrm{HC}$.

\section{CONCLUSION}

The aim of the article was to discuss harmful impact of different components of exhaust gases generated by vehicles and to describe one of the promising ways of exhaust gases neutralization by means of catalysts on the blocks. The authors collected and systematized the data published in modern domestic and foreign scientific sources.

With the growth of road transport, the use of which in the national economy and modern technology is increasing, the pollution of atmospheric air by exhaust gases increases. In the process of burning liquid fuel in the cylinders of engines, combustion products appear in the form of carbon dioxide, carbon monoxide, water, and other compounds. Pollution of all components of the environment (air, water, soil, food products) increased due to the intensification of human activities and the emergence of new factors, the negative impact on nature among them the further development of all modes of transport. There is a need to study in detail and classify various man-caused pollution of the environment, to foresee them, to prevent, reduce and neutralize the consequences of various negative human actions on nature.

Among all the ways to reduce the toxicity of man-made emissions into the atmosphere, catalytic oxidation of harmful components is one of the promising methods of improving the atmosphere.
It is clear, that despite the large number of studies on the catalytic purification of diesel exhaust gases from $\mathrm{NO}_{x}$ impurities and individual advances the problem of $\mathrm{NO}_{x}$ purification is still not solved. A sufficiently efficient and selective catalyst was not found to ensure the decomposition or reduction of $\mathrm{NO}_{x}$. In recent years, the attention of researchers has been directed toward the creation of cyclic systems in which, in the first stage, $\mathrm{NO}_{x}$ is absorbed by the main adsorbent, for example $\mathrm{BaO}$, and in the second stage decomposition or reduction of the absorbed $\mathrm{NO}_{x}$ occurs. Usually, noble metals are used in combination with alkaline earth oxide deposited on $\mathrm{Al}_{2} \mathrm{O}_{3}$ or $\mathrm{CeO}_{2}$. Under the process conditions, unwanted reactions can occur: sulfur poisoning, thermal sintering to form metal crystals, and reaction of $\mathrm{BaO}$ with the carrier to form $\mathrm{BaAl}_{2} \mathrm{O}_{4}$ and $\mathrm{BaCeO}_{3}$. Also, there is the problem of "cold start" of ICE, in which catalysts not heated up to $300^{\circ} \mathrm{C}$ do not reach the set operating mode and the composition of the exhaust gas engine is $60 \%$ more toxic than when operating under the load.

The applicability of the latest catalytic systems requires the presence of sophisticated electronic control systems for the combustion process in the engine, which is interrelated with a constant rapid analysis of the quality of the neutralizer and the composition of the exhaust gases.

It is very important to reduce emissions of $\mathrm{NO}_{2}$ and particulate matter (soot), carrying out qualitative tests of catalysts in real conditions for obtaining more complete information on the operation of catalytic converters.

It is necessary to tighten regulatory emissions in a legislative way because the purification of exhaust gases from motor vehicles and chemical industries is a scientific, technical and social problem.

\section{ACKNOWLEDGEMENT}

We would like to express sincere gratitude to the Ministry of Science and Education of the Republic of Kazakhstan for grant financing (Project 2018-2020).

\section{Conflict of interest}

Conflict of interest declared none. 


\section{REFERENCES}

1. Bahadori, A., Pollution Control in Oil, Gas and Chemical Plants, Springer., 2014, 212-223.

2. Hardisty, P. E. Environmental and economic sustainability, CRC Press Taylor \& Francis Group., 2010, 195-201.

3. Sassykova, L.R., Technogenic emissions into the atmosphere: impact on the environment and neutralization by catalytic methods, Almaty: Qazaq University, 2018, 123-128.

4. Vorobyov, A.E.; Dyachenko, V.V.; Vilchinskaya, O.V.; Korchagina, A.V., Environmental management bases: ecological, economic and legal aspects, Manual, Ed. Dyachenko, V.V., Rostov N / D, Phoenix., 2006, 421-434 .

5. Shevelyova, A.V., Bulletin of the MGIMO University., 2016, 48(3), 221-225.

6. Fedyaeva, O.A., Industrial ecology: Lecture notes, Omsk, Omsk State Technical University Publishing House., 2007, 105-114.

7. Aubakirov, Y.A.; Sassykova, L.R.; Starikov, E.B., International Journal of Biology and Chemistry., 2016, 9(2), 45-50.

8. Sassykova, L.R., Chemical and Biochemical Engineering Quarterly., 2017, 31(4), 447-453.

9. Abrosimov, A.A., Ecology of processing of hydrocarbon systems, Manual, Ed. Dolomatov, $M$. Yu.; Telyashev E.G., M., Chemistry., 2002, 235-244.

10. Mytareva, A.I., Selective catalytic reduction of NOx with ammonia on composite catalysts, Dissertation of the candidate of chemical sciences, M., 2017, 115-122.

11. Acid rain and transported air pollutants: Implications for public policy, Office of Technology Assessment, Congress of the United States, Washington, DC., New York, Unipub., 1985, 132-135.

12. Fenimore, C., $13^{\text {th }}$ International Symposium on Combustion., 1971, 13(1), 373-380.

13. Sassykova, L.R.; Nalibayeva, A.M.; Gil'mundinov, Sh.A., Bulgarian Chemical Communications., 2017, 49(3), 583-588.

14. Sassykova, L.R.; Nalibayeva, A.; Aubakirov, Y.; Tashmukhambetova, Zh.; Otzhan, U.; Zhakirova, N.; Faizullaeva, M., Orient. J. Chem., 2017, 33(4), 1941-1948.

15. Baiseitov, D.A.; Tulepov, M.I.; Tursynbek, S.; Sassykova, L.R.; Nazhipkyzy, M.; Gabdrashova, Sh. E.; Kazakov, Y. V.; Pustovalov, I. O.; Abdrakova, F.Y.; Mansurov,
Z. A.; Dalton, A. B., Rasayan J. Chem., 2017, 10(2), 344-348.

16. Tulepov, M.I.; Baiseitov, D.A.; Gabdrashova, Sh.E.; Sassykova, L. R.; Kazakov, Y.V.; Tursynbek, S.; Toshtay, K.; Pustovalov, I.O.; Abdrakova, F.Y.; Mansurov, Z.A.; Dalton, A.B., Rasayan J. Chem., 2018, 10(4), 1145-1150.

17. Rozovskii, A.Y.; Lin, G.I., Izv. RAN, Ser.Khim., 2004, 11, 23-52.

18. Raj, C.S.; Sendilvelan, S., International Journal of Automotive and Mechanical Engineering., 2010, 2, 144-146.

19. Tulepov, M.I.; Gabdrashova, Sh.E.; Rakhova, N.M.; Sassykova, L.R.; Baiseitov, D.A.; Elemesova, Zh.; Korchagin, M.A.; Sendilvelan, S.; Pustovalov, I.O.; Mansurov, Z.A., Rasayan J. Chem., 2018, 11(1), 287-293.

20. Sassykova, L.; Nalibayeva, A., Journal of Chemical Technology \& Metallurgy., 2018, 53(2), 289-295.

21. Sassykova, L.; Bunin, V.; Nalibayeva, A.; Nurakhmetova, M., Journal of Chemical Technology \& Metallurgy., 2018, 53(3), 537-542.

22. Sassykova, L.R.;Aubakirov,Y.A.;Kosmambetova, G.R., International Journal of Biology and Chemistry., 2017, 10(1), 84-88. https://doi. org/10.26577/2218-7979-2017-10-1-84-88.

23. Sassykova, L.R.; Ussenov A.; Massenova, A.T.; Gil'mundinov, Sh.A.; Rakhmetova, K.S.; Bunin, V.N.; Basheva, Zh.T.; Kalykberdiyev, M.K., Int J. Chem. Sci., 2016, 14(1), 206-212.

24. Assad, M.S.; Penyazkov, O.G., Combustion products of liquid and gaseous fuels: education, calculation, experiment, Minsk, Belaruskaya Navuka., 2010, 302-304.

25. Hunicz, J.; Alejandro, M., Energy., 2016, 117, 388-397.

26. Wojciechowska, M.; Lomnicki, S., Clean Prod. Processes., 1999, 1(4), 237-247.

27. Ertl, G.; Knözinger, H.; Schüth, F.; Weitkamp, J.(Eds.), Handbook of Heterogeneous Catalysis, Weinheim : Wiley-VCH., 2008, 123-142.

28. Taylor, K.C.; Automobile catalytic converters in: Crucq, A.; Frennet, A. (eds.): Catalysis and Automotive pollution Control, New York, Elsevier., 1987, 97-116.

29. Aubakirov, Y.A.; Sassykova, L.R.; Nalibayeva, A.M.; Dossumov, K., Tashmukhambetova, Z.K.; Zhumakanova, A.S.;Zhussupova, A.K.;Zhakirova, 
N.K., Orient. J. Chem., 2017, 33(6), 3130-3137.

30. Bhaskar, K.; Sendilvelan, S.; Muthu, V.; Aravindraj, S., Journal of Mechanical Engineering and Sciences., 2016, 10(2), 1994-2007.

31. Burdeinaya, T.N.; Matyshak, V.A.; Tret'yakov, V.F.; Glebov, L.S.; Zakirova, A.G.; Garcia Carvajal, M.A.; Villanueva, A.M.E., Applied Catalysis B: Environmental., 2007, 1(4), 128.

32. Burke, N.R.; Trimm, P.L.; Howe, R., Proceedings. Pt.B. $12^{\text {th }}$ Int.Congress on Catalysis, Granada, 2000, July 9-14, Elsevier, 2000, 1451-1456.

33. Sassykova, L.; Gil'mundinov, Sh.; Nalibayeva, A.; Bogdanova, I., Rev. Roum. Chim., 2017, 62(2), 107-114.

34. Sendilvelan, S.; Bhaskar, K., Orient. J. Chem., 2017, 33(4), 2111-2117.

35. Sassykova, L.R.; Nalibayeva, A., News of NAN RK, Series of Chemistry and Technology., 2017, 421(1), 9-15.

36. Kotler, V.R., Oksidy azota $v$ dymovykh gazakh kotlov, Moskva, Energoatomizdat., 1987, 114-124.

37. Grewe, V.;Dahlmann, K.; Matthes, S.; Steinbrecht, W., Atmos. Environ., 2012, 59, 102.

38. Zel'dovich, Ya.,B.; Sadovnikov, P.Ya.; FrankKamenetskiy, D.A., Okisleniye azota pri gorenii, Moskva, Izdatel'stvo AN SSR., 1947, 116-125.

39. Nalibayeva, A.; Sassykova, L.R.; Kotova, G.N.; Bogdanova, I.O., News of NAS RK, Series Chemistry and Technology., 2016, 419 (5), 55-64.

40. Klingenberg, H., Automobile Exhaust Emission Testing: Measurement of Regulated and Unregulated Exhaust Gas Components, Exhaust Emission Tests, Berlin, Heidelberg :Springer-Verlag., 1996, 233-238.

41. Warnatz, J.; Maas, U.; Dibble, R.W., Combustion physical and chemical fundamentals, modeling and simulation, experiments, pollutant formation, Berlin, Springer-Verlag., 2006, 333-337.

42. Technical bulletin, Nitrogen oxides (NOx): Why and how they are controlled, U.S. Environmental protection agency, Research triangle park, North Carolina: Office of air quality planning and standards., 1999, 14-18.

43. Sperling, D.; Gordon, D., Two billion cars: driving toward sustainability, New York, Oxford University Press., 2009, 312-320.

44. Number of cars sold worldwide from 1990 to 2016 (in million units), Statista the statistics portal, URL: ttp://www.statista.com/ statistics/200002/international-car-salessince-1990., 2016.

45. Kašpar, J.; Fornasiero, P.; Hickey, N., Catal. Today., 2003, 77(4), 419-449.

46. Akhmetkaliyeva, M.; Sassykova, L.R., Aubakirov, Y.A.; Sendilvelan, S.;Zhumakanova, A.S.; Abildin, T. S.; Zhussupova, A.K.; Amangeldi, M. B., News of the National Academy of Sciences of the Republic of Kazakhstan, Series of Geology and Technical Sciences., 2018, 429(3), 20-29.

47. Akhmetkaliyeva,M.Sh.;Sassykova, L.R.;Aubakirov, Y.A.; Sendilvelan S., International Journal of Biology and Chemistry., 2017, 10(2), 40-44.

48. Sassykova, L.R.; Aubakirov, Y.A.; Bunin, V.N.; Sendilvelan, S., International Journal of Biology and Chemistry., 2017, 10(2), 54-61.

49. Orazbayeva, D.S.; Karatayeva, U.A; Kenessov, B.N.; Beysembayeva, K.A.; Meyramkulova, K.S., Chemical Bulletin of Kazakh National University., 2016, 2, 36-40.

50. Carlsen, L.; Baimatova, N.; Kenessov, B.; Kenessova, O., International Journal of Biology and Chemistry., 2013, 5(1), 49-69.

51. Bizhaev, A. V., Improving the environmental safety of a tractor diesel by adding water to cylinders, dissertation of a candidate of technical sciences, Moscow, Russia., 2016, 161-167.

52. Sassykova, L. R.; Basheva, Zh. T.; Kalykberdyev, M. K.; Nurakhmetova, M.; Massenova, A. T.; Rakhmetova, K. S., Bulg. Chem.Comm., 2018, 50(1), 82-88.

53. Zheksenbaeva, Z.T.; Tungatarova, S.A.; Baizhumanova, T.S.; Shaizada, E., Chemical Engineering Transactions., 2015, 45, 1213-1218.

54. Dossumov, K.; Gilmundinov, Sh.A., XVIII International Conference on Chemical Reactors “CHEMREACTOR-18", Malta., 2008, 212-214.

55. Rakhmetova, K.S.; Sassykova, L.R.; Gil'mundinov, Sh.A.; Nurakhmetova, M.S.; Berdibekova, M.A.; Kalykberdiyev, M.K.; Massenova, A.T.; Basheva, Zh.T., News of NAS RK, Series Chemistry and Technology., 2016, 419(5), 111-117.

56. Tulepov, M. I.; Mansurov, Z. A.; Kazakov, Y. V.; Abdrakova, F. Y.; Sultanova, Z. L.; Rakhova, N. M.; Madiyev, S. S.; Golovchenko, O. Y.; Sassykova, L. R.; Tolep, D. M.; Chikhradze, N.; Chikhradze, M. N., Orient. J. Chem., 2018, 34(6), 3037-3043. 
57. Sokolova, L.A.; Popova, N.M.; Dosumov, K., React. Kinet. Catal. Lett., 1979, 10(3), 251.

58. Gilmundinov, Sh.A.; Sassykova, L.R.; Nalibayeva, A.M., Catalysis: Fundamentals and Application, Novosibirsk, Abstracts, VII., 2007, 4(8), 532-534.

59. Popova, N. M.; Umbetkaliev, A. K.; Dosumov, K.; Antonova, N.A., Reaction Kinetics and Catalysis Letters., 1996, 57(2), 255-262.

60. Sassykova, L.R.; Massenova, A.T.; Gilmundinov, Sh.A.; Bunin, V.N.; Rakhmetova, K.S., Tagungsbericht., 2014, 3, 181-188.

61. Gilmundinov, Sh.A.; Sassykova, L.R.; Nalibayeva, A.M.; Dossumov, K., International Symposium on Metastable and Nano Materials, ISMANAM, Corfu, Greece., 2007, 168-169.

62. Zheng, Qinghe (Angela), Catalytic abatement of environmental pollutants and greenhouse gases in automotive, natural gas vehicles, and stationary power plant applications, Thesis, Columbia University., 2016, 63-76.

63. Gasparyan, M.D., Localization of volatile radionuclides on ceramic highly porous blockcell materials in the processes of handling radioactive waste and spent nuclear fuel, the Dissertation of the doctor of Technical Sciences, Moscow., 2016, 132-142.

64. Antsiferov, V.N.; Kalashnikova, M.Yu.; Makarov, A.M.; Porozova, S.Ye.; Ekologiya $i$ promyshlennost' Rossii., 1998, 3, 19-20.

65. Liberman, E.Yu.;Naumkin, A.V.; Mikhailichenko, A.I.; Batrakova, M. K.; Maslakov, K. I.; Revina, A.A.; Papkova, M.V.; Kon'kova, T.V.; Grunskii, V.N.; Gasparyan, M.D.; Karpovich, A.L.; Lizunova, A.A., Russian Journal of Physical Chemistry A., 2015, 90(1), 166-172.

66. http://wiki.ask.com/Catalytic_converter.

67. Grunskiy, V.N.;Bespalov, A.V.; Davidkhanova, M. G.; Popova, N.A.; Kharitonov, N.I., Khimicheskaya promyshlennost' Segodnya., 2016, 6, 9-15.

68. Patent US 5883041, Pak, V.N.; Kopylov, V.B., Composite catalyst for purifying exhaust gases from carbon monoxide and organic compounds., 1999.

69. Sassykova, L.R.; Gil'mundinov, Sh.A.; Massenova, A.T.; Akimbaeva, Zh.A.;
Gasparyan, M.D.; Kalykhberdyev, M.K.; Nurakhmetova, M.S.; Grunskii, V.N.; Kenzin, N.R., News of NAS RK, Series Chemistry and Technology., 2016, 416(2), 135-144.

70. Grunskiy, V.N.; Kozlov, I.A.; Bespalov, A.V.; Gasparyan, M.D.; Lukin, Ye.S.; Starodubtseva, O. V.; Ogneupory I Tekhnicheskaya Keramika., 2011, 6, 18-21.

71. Bakunov, V.S.; Belyakov, A.V.; Lukin, Ye.S.; Shayakhmetov,U., Oksidnaya Keramika: Spekaniye I Polzuchest', M., RKHTU Im. D. I. Mendeleyeva., 2007, 534-543.

72. Gurkan, K.; Junko, M-W.; Umit, S.O., Catal. Commun., 2002, 3(5), 199-206.

73. Haggin, I., Chem. \& Eng. News., 1993, 71(15), 34-36.

74. Zhenjin, K.; Zhenchuan, K., Journal of Rare Earths., 2006, 24, 314-319.

75. Zhang, R.; Alamdari, H.; Kaliaguine, S., Appl. Cat.B:Environmental., 2007, 72, 331-341.

76. Strizhak, P.E.; Trypolskyi, A.I.; Kosmambetova, G.R.; Didenko, O.Z.; Gurnyk, T.N., Kinetics and Catalysis., 2011, 52(1), 128-138.

77. Sendil velan, S.; Jeyachandran, K.; Bhaskar, K., SAE Technical Paper 2001-01-2000, 2001, doi:10.4271/2001-01-2000.

78. Bhaskar, K.; Sendilvelan, S.; Sassykova, L.R., News of the National Academy of Sciences of the Republic of Kazakhstan, Series of Geology and Technical Sciences., 2018, 428(2), 6-17.

79. Sendilvelan, S.; Bhaskar, K., Journal of Chemical and Pharmaceutical Sciences., 2017, 10(1), 46-49.

80. Venkatesh, B.R.; Sendilvelan, S., Global Journal of Research Engineering., 2011, 11(2), 11-15.

81. Bhaskar, K.; Sassykova, L.R.; Prabhahar, M.; Sendilvelan, S., International Journal of Mechanical and Production Engineering Research and Development., 2018, 8(1), 399-406.

82. Prabhahar, M.; Sendilvelan, S.; Sassykova, L.R., Indian J. Environmental Protection., 2018, 38(4), 269-277.

83. Sendilvelan, S.; Jeyachandran, K.; Bhaskar, K., Spring Technical Conference, IC Engine Division of ASME., 2001, 36, 1. 